\title{
Love Stories and Hot Summers A Reflection on Romance, Youth and a Socialist Musical
}

\section{Ruth Crawford}

This paper situates the musical film, Heisser Sommer, within a discourse of negotiation between party and populace in the GDR which revolved around the politicisation of romance. It looks at the film within the larger context of attempts by the government in the GDR to embrace popular culture, and its ultimate failure to do so effectively despite its intrusion into the private sphere in other areas of everyday life, while also exploring the film's place in the wave of GDR-nostalgia following German reunification.

Keywords: musical film, popular culture, socialist personality, DEFA, nostalgia.

Fifty years after its release, Joachim Hasler's youth musical film Heisser Sommer (1968) was turned into a musical theatre production and premiered, with its two main stars as guests of honour, at the Eduard-von-WintersteinTheater in Annaberg-Buchholz in Saxony in July 2018 (Die deutsche Bühne). A similar experience was offered to theatre goers at the Boulevard Theater in Dresden in September that year (Boulevard Theater). The audience had the opportunity to hear an interview with one of the film's musical directors to mark the film's anniversary. Film showings have occurred throughout former East Germany in the last couple of years, from the Museum Schloss und Festung Senftenberg in the Lausitzer Seenland $\left(26^{\text {th }}\right.$ July, 
$2018)$ to the Pöge-Haus in Leipzig $\left(10^{\text {th }}\right.$ August, 2018), from the Hofkino in Berlin (28 ${ }^{\text {th }}$ August, 2018) to Rosa Luxemburg Stiftung in Schwerin $\left(15^{\text {th }}\right.$ December 2018). In many ways, the continued popularity of this film is not surprising, but it is illuminating. The film illustrates how romance and private fulfilment were sites of constant negotiation between party and populace, and demonstrates how the German Democratic Republic tried to use popular culture to communicate with and to its younger citizens about life in socialism.

Heisser Sommer was among a small number of film musicals produced and released over the course of the GDR's history $^{1}$. It was also one of DEFA's biggest homemade hits (Heiduschke 85) and, as evidenced above, still holds a particular place in the hearts of former GDR citizens and their children who, like other members of the younger generations in the audience at these film screenings or theatre shows, may have never really lived in the GDR. Despite the film's popularity, or perhaps because of it, the film's place in GDR film scholarship is still marginal, although there have been attempts recently to integrate it into the growing body of scholarship on genre in GDR film.

The nature and history of musical film and the specific subject matter mean that this film embodies some of the complexities informed by authoritarian attempts to model ideal citizens. It is important to position this argument within the body of more recent scholarship into GDR society and culture, which has concentrated on the dialogic nature of community life and political reality in the GDR. Although the totalitarian and repressive aspect of the regime can and will not be denied, understanding how

\footnotetext{
${ }^{1}$ See Rinke and Raundalen for more comprehensive explorations of the genre within DEFA's production history.
} 
authoritarianism maintains its power and, indeed, its appeal, must also draw on acknowledging the discourse of mutual negotiation between state and society, and the role of this discourse in shaping individual and collective identities. In this discussion, I will examine some of the aforementioned complexities and highlight why, perhaps, this film remains a fascinating illustration of how the goals and methods of real-existing socialism were so riddled with contradictions.

\section{"True love belongs to youth the way that youth belongs to socialism" ${ }^{2}$ Creating and controlling young socialist personalities}

The above quote is from a communiqué issued by the ruling Socialist Unity Party in 1963 to explain the party's, and therefore, in the GDR, the government's, attitude towards and concern with young people. A further exploration of this attitude allows us to understand the contradictions of daily life in the GDR. It demonstrates quite effectively the complexity of the relationship between state and populace in the GDR: youth belonged to socialism in as much as the state wanted to project itself as a forward-looking entity, hence as the future, which was breaking away from Germany's Nazi past and trying to create a progressive way of life in a new state. As such, the state needed youth to support it and justify and exemplify its politics, guaranteeing its future. However, the state, and its form of real socialism, also belonged to youth. The state was there to instil the desired new 'socialist personality' in its young citizens, so as to ready them to carry the flag of these ideals into the future. In the Wörterbuch zur sozialistischen

${ }^{2}$ qtd in Herzog 196. 
Jugendpolitik from 1975, the 'socialist personality' was described thus:

An all-round, well-developed personality, who has a comprehensive command of political, specialist and general knowledge, possesses a firm class outlook rooted in the Marxist-Leninist world view, is notable for excellent mental, physical and moral qualities, is thoroughly imbued with collective thoughts and deeds, and actively, consciously and creatively contributes to the shaping of socialism. (qtd. in Fulbrook 115)

The reciprocity inherent in the socialist personality as described here - as one who has been shaped by socialism but also in turn helps to shape it - is typical of the ideological negotiation between state and individual mentioned above. This was a state where "social reality involved surprisingly complex negotiations between rulers and the ruled," and which saw, to a large extent, the replacement of "brute force with indirect incentives." (Jarausch 5).

Another complexity involved in the creation of the socialist personality and which should be mentioned here is the specificity of East Germany when discussing Sovietinspired and -led state socialism. The GDR was geographically and ideologically between two worlds: diametrically opposed socially and politically from its neighbours in the West, and yet also historically different from its neighbours in the East. Whereas other Eastern-bloc governments and societies always had recourse to a call to nationalism in either attempting to shape or resist state power, this remained essentially impossible in East Germany for two reasons. Primarily, the German nation 
itself was a contested issue - there were two Germanies, both struggling for primacy and claiming to embody the true 'essence' of Germanness. Secondly, German nationalism was an issue fraught with historical complications for a state machinery founded on professed anti-fascism.

The East German state therefore also faced problems concerning its own self-image and rhetorical positioning. Dorothee Wierling explains that although the GDR state was unable to call upon the traditional symbols of nation automatically, it also was under pressure to construct a relationship with its citizens that went beyond the political. Therefore, she argues, it constructed a discourse of love familial, platonic and on occasion romantic - to describe and guide its relationship with its citizens.

„Durch ... Anleihen an die Vorstellungen von der Nation als Gemeinschaft, als einem lebendigen Organismus, als abstrakter Repräsentation von Heimaterde und Volkskörper wurde die DDR zwar nicht explizit als Nation imaginiert, aber ihr wurden doch emotional stark besetzte Eigenschaften zugeschrieben, die denen der Nation ähnelten. Der Staat DDR war aber nicht nur Ausdruck von Gemeinschaft und Heimat, sondern auch von Fortschritt und Zukunft.... Die DDR als Staat wird von ihm personalisiert, indem sie als Empfängerin von Anerkennung, Verehrung, vor allem: Liebe imaginiert wird." (237-8)

This need to love and be loved can be seen in the state's attitude towards morals and youth, which was at times 
open to suggestion and - in strictly heteronormative terms - liberal, and at other times paternalistic and authoritarian ${ }^{3}$. Looking at the official record of everyday life in East Germany, it would be easy to assume that the government attempted to regulate every aspect of the lives of young people. There were organized activities, youth groups, choirs, drama groups, nurseries and holiday camps, all of them under the auspices of official associations. However, studies have also revealed that although the majority of young people participated in such activities, almost all were relatively savvy regarding the 'political agenda' behind them. Moreover, many initiatives stemmed from popular practices which were not originally sanctioned by the regime. For example, further along in the communiqué quoted earlier, there was a promise from the Youth Commission to give young people more trust and responsibility, and shortly thereafter, a number of youth festivals and youth radio stations were set up to counter radio stations from the West and to encourage the development of the independent live music scene in a more socialist manner. Similar developments occurred with television and in the film industry, when the State would look to what the people were watching, mostly broadcast from the West, and then make their own, more politically acceptable versions in the East (Fulbrook 130ff).

Yet it was not just in the arena of culture that the battle for young East German hearts and minds was fought. In the area of morality and sexuality there were similar exchanges between government and populace in order to find a situation acceptable to both. One of the most frequently investigated examples of this involves the history of

${ }^{3}$ See here also Julia Hell's argument about the construction of the totalitarian project around the family in GDR foundational narratives. 
abortion in East Germany, where harsh restrictions and pro-natalist incentives in the initial years met with resistance and no significant rise in the birth rate occurred until the early 1970s, when a relaxation of abortion restrictions was paired with a number of financial and structural provisions designed to help women combine their roles as mothers with the other aspects of their lives ${ }^{4}$. By the end of the 1980s, East Germany had some of the healthiest population figures in all of Europe. This give and take between state and people can also be seen in the GDR's attitude to heterosexual sex.

The GDR was quick to distance itself from the West and its post-war conservatism regarding premarital sex, contraception and the role of women. There was certainly initial conservatism, but the absence of any church involvement in official proceedings or debates, in addition to the desperate need to repopulate the country, led to relatively liberal laws and attitudes regarding unwed mothers and premarital sex. Indeed, in the $60 \mathrm{~s}$ and $70 \mathrm{~s}$, as the sexual revolution was beginning to take hold in the West, essays and magazines in the East, as well as sex handbooks, were encouraging parents to let go of their bourgeois morality and to be understanding of young love. At the same time, however, there were very concrete efforts to define it.

${ }^{4}$ For a discussion of the role of citizen negotiation and letter writing in policy change, see Harsch. Further details on the evolution of these policies can be found in von Ankum's and Grossman's works. 
In the section entitled "Partnerwahl" in the Kleine Enzyklopädie: Die Frau published in 1961, love was defined thus:

Liebe ist die Begegnung zweier Menschen verschiedenen Geschlechts in körperlich-seelichgeistiger Hinwendung, Auseinandersetzung und gegenseitiger Entwicklung. Sie bringt Übereinstimmung und Ergänzung. Liebe sucht nicht nur den eigenen Genuß, sondern das Glück des anderen. Im Denken, Fühlen und Handeln tritt das "Du" vor das "Ich". Wahre Liebe ist gegenseitig und ausschließlich, dauerhaft und verläßlich; sie setzt die Achtung vor dem anderen voraus und bedeutet: sich kennen, sich vertrauen, sich verstehen. ... Für zwei Menschen, die eine Ehe eingehen wollen, ist es in erster Linie wichtig, zu erproben, ob ihre Gefühle füreinander wirklich dauerhaft und verläßlich sind. Erst dann sollen sie sich für ein gemeinsames Leben entscheiden. (63)

There is a clear focus on the folly of youthful urges and a plea for restraint, although alongside this there is a clear acknowledgement of such urges. This was developed further two years later in the SED's memorandum on youth, which stated that "every true love between two people deserves candid respect" (qtd. in Herzog 195). This more liberal attitude towards both love and sexuality, although still heteronormative, proved incredibly popular. Soon the government turned this to its own advantage, often claiming that relationships and sex itself were more liberated, liberal and gratifying in the East because, thanks to the legal and economic independence of women, no woman felt she had to find a partner she was unhappy with because of financial issues. 
Yet, there remained in official documents and attitudes a suspicion that romance and passion might ultimately steal the couple's energy away from socialism and might make them - as private individuals - break away from the state and collective. The GDR's goal then, according to Dagmar Herzog in her book Sex after Fascism, was to create an atmosphere in which sex and socialism could go hand in hand, where romance involved not only the two individuals, but also to some extent, the state. ${ }^{5}$ This ambiguous attitude towards romance and passion: the desire to create an environment where romance is not only possible, but it is probably of a far higher quality than in the West, while at the same time not allowing private romance to take precedence over the public, is especially apparent in the GDR's only youth musical, Heisser Sommer.

"The question remains whether it is advisable for the DEFA to dedicate its efforts to musical film. Frankly, this genre is the most flagrant offspring of the capitalist pleasure industry": ${ }^{6}$ Entertaining young socialist personalities

It is important to position Heisser Sommer within the political development of DEFA. The GDR film industry was tasked, following the establishment of the socialist state, with providing entertainment that also adhered to real socialist principles. As Colonel Sergei Tulpanov, director of the Propaganda Administration of the Soviet Military Administration in East Germany, put it in 1946, this meant to "struggle to re-educate the German people - especially

\footnotetext{
${ }^{5}$ See Betts, Chapter 3 and Urang, who both discuss the legal and cultural framing of love and family in the GDR.

${ }^{6}$ qtd in Ranga 1997
} 
the young - to a true understanding of genuine democracy and humanism, and in so doing, to promote a sense of respect for other people and other nations. (qtd. in Allan and Sandford, 3). Staking their claim to legitimacy on their anti-fascism and on their credentials as left-wing intellectuals in pre-war Germany, many of the cultural elite within the new socialist state felt that it was the responsibility of the arts to combat fascism and capitalism. The mission of DEFA was then to capture "diese aufgehende Sonne der sozialistischen Arbeit, des sozialistischen Bewußtseins in Ihren Scheinwerfern und Kameralinsen" (qtd. in Berghahn 184). With this and other rather lofty mission statements in the early 1950s, a time that also witnessed increasing political turmoil in East Germany, DEFA films were often rather didactic and serious, and were not well-received by the general viewing public. As citizens of the GDR could cross quite easily into West Germany until 1961 when the Berlin Wall was constructed, many cinema goers did exactly that in order to watch more entertaining films in the West. Uta Poiger cites internal East German estimates that up to 26000 citizens were crossing the border every day to go to the cinema in 1956-57. The cinemas that they visited showed mostly American films (85). Even after the Berlin Wall was constructed, East Germans overwhelmingly preferred Western films (Heiduschke 2013 21) and as Horten explains, this led to a situation in the 1970s and 80s, where “the GDR's cultural film policy was increasingly driven by economic necessity and overwhelming consumer demand, while ideological concerns took a back seat" (71).

The close alliance between DEFA and the government of the GDR meant that filmmakers and artists had little or no control over the subjects they were allowed to cover. And it also meant that they were more susceptible to outside 
influences. Thus, the film industry in the GDR suffered from constant fluctuation between dogmatic, hard-line programming and more liberal periods of aesthetic experimentation. The making of Heisser Sommer took place against the background of the $11^{\text {th }}$ Plenary in 1965, where some films deemed particularly critical of the socialist state were banned. Their writers and directors were publicly criticized and required to submit public apologies. Some were even banned from making further films.

In light of this, it is easy to judge this film as essentially apolitical and aesthetically derivative, but the film and its producers did have to perform a balancing act. It had to show on the one hand what a fun place the GDR was if you were a teenager - a place where you could live out your little rebellions and grow on your own, yet still be accepted back into the fold at the end of the day. On the other hand, the film had to make sure that socialist principles were obeyed, and that the rebellions were ultimately part of a learning experience designed to make the rebel a better citizen. This film also fulfilled an important task for DEFA. The popularity of the cinema in East Germany remained high among young people, even after the construction of the Berlin Wall. However, as mentioned above, and as detailed by Heiduschke, viewing figures for DEFA were constantly under pressure from both Western film imports and - later on - West German television. Directors had to try and ensure entertainment, and therefore higher viewing figures, as well as a political message which suited the Party. One communique from the Central Committee of the Socialist Unity Party stated that "a well-attended showing of a DEFA film has more propagandistic effect than a political meaning. With these films we can reach those bourgeois and indifferent people who are avoiding our meetings" (qtd in Ranga). The film, then, had to appeal to 
large sections of the population and serve the state without being expressly political, and to a large extent, Heisser Sommer achieved this dual - and somewhat contradictory function.

It tells the story of two groups of youths going to spend their summer on the Baltic coast, working and having fun. Ten boys and eleven girls meet while hitchhiking to what is ultimately the same resort, and of course, hi-jinks ensue. Romantic entanglements, relatively minor examples of delinquency and ostracism are all part of the plot which is interspersed with songs, some of which develop the plot and some of which do not. The final shot of the film has all twenty-one of the teenagers lying on the beach in solidarity and performing in harmony together as a group, rather than with the idolization of a single romantic pairing. There is a narrative disjunction between this ending and the development of the story, and it is this gap where a reading of the film as simultaneously compliant and subversive should become possible. Despite being a star vehicle for a celebrity couple, and despite being the story of a group holiday of young people who are relatively unencumbered by adult supervision, romance is ultimately frustrated.

The narrative of the film revolves around the love triangle between two boys, Kai and Wolf, and one girl, Brit. Brit seems to be the most sexually aware of the girls, and is calm and aloof. She initially pairs off with Wolf, the 'Casanova'-figure; however Kai, the more responsible and wholesome group leader, is also interested in her. Brit cannot make up her mind between them and meets with both repeatedly over the space of one day and night. In pursuing them, she annoys her companions and betrays both boys. This leads to inevitable confrontations, the first of which takes place on a stolen boat, leading to a run-in with authorities, and then ultimately, to a very dramatic 
fist-fight on a cliff-top. The boys are eventually released without charge for the boat-stealing incident, and order is restored; however, both Brit and Wolf, who have been ostracized by the group for their selfish behavior, decide to leave their groups and the island. They fail to do so, however, as the rest of the group acquiesces and invites them back at the last minute and everyone relaxes happily on the beach together.

Its huge success at the time of its release was due to a number of factors, including the involvement of Chris Doerk and Frank Schnöbel, two of the GDR's biggest popstars, in the roles of Stupsi, the other female lead, and Kai. In addition, the deliberate attempt to incorporate modern and 'western' styles of music, and the fact that it was one of the few films actually made by DEFA with the express intention of appealing to teenagers contributed to its success. However, its popularity was also boosted by the events of 1968, when Soviet tanks rolled into Prague in order to crush the increasingly liberal government there. Heisser Sommer provided much needed escapism in the face of political turmoil, and also perpetrated several rather inaccurate fantasies about the lax nature of the law, the ease of travel and the carefree nature of the GDR, while taking advantage of a popular international genre. This clearly makes the film compliant with the GDR's attempt to bury in silence the politically critical situation.

The use of genre-films was not unknown in the GDR. DEFA also had considerable success with both western films and science fiction. Both of those genres, however, were much more in tune with socialist principles than the musical. In DEFA westerns, it was politically acceptable to paint the cowboys as violent, capitalist oppressors, and science-fiction, with its focus on the future and scientific 
progress, was also politically workable ${ }^{7}$. In contrast, musicals were seen as the quintessentially American genre, representing decadence and hedonistic consumerism at their worst. In his essay on utopia and entertainment, Richard Dyer describes Hollywood musicals as having an ideological structure, which sells marriage, promotes stability within the community, maintains gender roles and sells the wonders of capitalism (1977 3ff). Most theories concerning musicals agree that, with some exceptions, they are essentially a conservative form, which serves to assimilate difference and ultimately to sell the community as a safe environment, free from paradox and threatening diversity. ${ }^{8}$ This interpretation, with the exception of the capitalist flag-waving, should mean that traditional, Hollywood-type musicals would be well-suited to socialist purposes, and indeed musicals in the Soviet Union were hugely popular and film makers there managed to adopt the genre to their political programme. However, most Soviet musicals were aimed towards an older audience than Heisser Sommer, and the prospect of a youth musical was a challenge for DEFA: in order to assimilate difference and paradox, these must ultimately be shown to exist in the first place. This was a risk that film makers in the late 1960s in East Germany were unwilling to take.

The genre of the musical carries with it certain cinematic conventions, which Altman (1999, 32ff) identifies as music, dance, settings and iconography. Some of these are adhered to in Heisser Sommer, some proved less compatible with the

\footnotetext{
${ }^{7}$ See here Berghahn, especially Chapter 1 . See also Fritzsche, Torner and Soldovieri for more detailed discussions of these particular genres.

${ }^{8}$ Of course, there are also a lot of examples of film musicals, both American and European, which subvert this model, some of which are discussed by Marshall and Stilwell.
} 
film's political goals, and it is useful to see how DEFA adapted these conventions for its own purposes. Stylistically, a musical presented formal problems for GDR film makers. It is by its very nature decidedly anti-realist, and also required very specific talents from its makers and cast. A big problem for film makers who wanted to experiment with this genre was the fact that because so few were made, finding actors who had acting, singing and dancing training was difficult. The choreography and dancing in Heisser Sommer are decidedly amateurish, something which undoubtedly increased its appeal by adding extra comedy and allowing viewers to relate more to the protagonists. It also allowed DEFA to detract from criticisms that they were mimicking a corrupt Hollywood genre too closely.

The music in the film covers a variety of styles: romantic ballads, attempts at a more vigorous rock ' $\mathrm{n}$ ' roll, and cheeky pop songs while some of the group numbers have overtones of military marches. Although this in itself is was an attempt to woo younger audiences with something new, it is interesting to note that the father-son duo responsible for writing the score had both been officially sanctioned as a DEFA composer and "an officially sanctioned proponent of cultural politics" respectively (Heiduschke 89). Politically, the music remained entirely on message for the State.

Settings in the film were also used to political effect. Although the majority of the film takes place on the Baltic coast, and shows the pastoral beauty of the East German countryside, there are also several incongruous elements which serve different purposes. When Kai and Stupsi sing a song together, for example, they go from the beach to the fields, then they are suddenly singing to each other while operating a hand car, then they are seen on top of a steam 
train, from which they jump off and miraculously end up inside two mini haystacks. This song was almost certainly designed specifically as a vehicle for featuring the pop stars and real-life couple of Doerk and Schnoebel; yet, the song and the sequence also manage to display the farming ideal of north-eastern Germany in complete harmony with machinery and progress. Again, Heisser Sommer seems here to celebrate the success of the politics of land collectivization the GDR had embarked on, initially, in the years of Soviet occupation, 1945-48, and that was officially launched by the SED in $1952^{9}$.

There are urban settings too. In the beginning of the film, the girls leave from Leipzig and the boys from Karl-MarxStadt, with panoramic views of both city centres demonstrating the new architectural achievements in these towns, and leaving out some of the more controversial planning decisions, such as the destruction of older buildings in Leipzig ${ }^{10}$. Kai also has a dream sequence in which he is dancing and singing with Brit around Berlin the architecture is pristine, and the city is delightfully clean and sunny and modern.

The issue of consumerism also crops up among the settings of the film. In the aforementioned dream sequence, Kai dances along the roof of the Café Moskva in Berlin amid clothing lines covered in women's shoes and swimming costumes, demonstrating the ability of the GDR to take care of its citizens' material needs and wants. As surreal as this

\footnotetext{
${ }^{9}$ See Caldwell and Bauerkämper for discussions of the collectivization.

${ }^{10}$ See here Fulbrook, chapter 3, for a detailed discussion of the pressures put on urban planners to provide housing in cities. See also Ladd, Bernhardt and Heckart for discussions of particular controversies.
} 
seems, these reappear in the background of another dream sequence, after the boat incident, when Kai tells Brit off in a song. The dream sequences themselves play an important role within the film, both breaking the narrative and allowing an exploration of Kai's inner conflicts. During the song, which is angry in tone, Brit dances along in the background under similar clothes lines filled with the same items. His association of Brit and her disruptive nature with consumerism shows the ambivalence that remained in the official attitude towards consumer goods and luxuries ${ }^{11}$.

It is not just in the association of Brit and her disruptive sexuality with consumerism that the film flirts with traditional, Western gender stereotypes. When we are introduced to the girls, they talk about make-up and calories, reinforcing stereotypes which were viewed as undesirable, at least officially, in the GDR. Moreover, the girls use their sexuality overtly and manipulatively: in order to get a lift while hitchhiking, they display a picture of Brit in a bikini, pinned on the side of a suitcase, and later on in the film all the girls offer the promise of romance and sex to play pranks on the boys' group.

This young and playful femininity is counterbalanced on the screen by the female farmers who give a lift to the young men, and offer them gainful work. These women are older and undesirable - sexually - to the young men, who run away amid promises that they'll maybe return in twenty years' time. This reinforces the self-image of the state as a workers' and farmers' state, but also demonstrates a rather self-conscious effort to poke fun at itself. It also reinforces the continuity of the state - they will be back to

\footnotetext{
${ }^{11}$ See Merkel and Landsman for a discussion of consumer culture in the GDR. Stitziel and Pelka both look at the particular issue of fashion within East Germany.
} 
do their part as workers and farmers. Traditional gender divisions of labour are further on show during the boat-trip section of the journey to the holiday. Both groups must travel by boat, but the boys' group have to help on their boat, and are all shown in work clothes, covered in oil and sweat. The girls, however, don bikinis and sit about on the deck sunning themselves, talking about the boys. Despite these reductive representations, the girls are shown as active participants in the film - they are instrumental to the advancement of the plot and engage fully in the minirebellions of the group.

It is important to note, though, that these rebellions are played out under the watchful eye of the authorities. The girls stay in a dormitory with a kindly supervisor who keeps their secrets while dishing out useful advice. The owner of the boat that is stolen is ultimately dissuaded from pursuing legal action by the local policeman who believes that rehabilitation is much more important than punishment. This is borne out when the boys offer to fix the damage to the boat themselves, demonstrating that their own sense of responsibility and community has not been damaged by the freedoms that they have.

These freedoms are heavily emphasized. The song that plays during the main titles, and, later in the film, details the fact that these young people want to experience something out of the ordinary, something which "doesn't happen every day," and that they want to go wild for once. The film shows that this is not only tolerated, but even encouraged in this beneficent, technicolour, socialist state. Despite the havoc that the groups wreak, the punishment they receive from the authorities seems relatively mild compared to the treatment that the three main transgressors receive from their peers. 
This stems from the primacy of the group, which is paramount in the film and cannot be challenged by an individual pairing. We see this in the dance moves themselves. Heiduschke comments that "in communal dance scenes, they do not exhibit a "naïve choreography," but transform the film into a socialist musical by displaying equality, mutual respect, and the rejection of leadership likely a reason why the characters played by Doerk and Schnöbel do not end up with each other in the end" (2013, 90). Indeed, it would have perhaps made sense to expect that the real-life celebrity couple would have ended up together. As Raundalen argues,

[this] would have drastically heightened the emotional impact of the happy end, but would simultaneously have contradicted the political morality tale that the cultural authorities [...] wanted to tell. In other words, the story in this case had to be 'tamed' in order to contain the possible emotional engagement by the audience in the love-story part of the narrative. $(2005,76)$

This explains why the romance element of the film is so stilted and unconvincing: individual romance should not threaten the collective.

The problem of romance, then, proves to be the biggest stumbling block for the film. The confrontations between the two groups generally involve gentle teasing and choreographed fights, but they, as Andrea Rinke has pointed out, lack sexual tension and remain platonic and unconvincing (2006, p.84). From the first meeting, pairing off seems inevitable - the boys even count the number of girls and comment that one of them will get at least two girls. When both groups arrive at the coast, the two main stars introduce their friends in such a way as to pair them 
off. As romance blossoms, the boys' group frequently form a spontaneous huddle in order to plan their next move visà-vis the girls, and both groups plot together to get the better of the other. However, the romances between the less visible members of the groups are shown in a comedic light, and promise little more than a holiday fling. The conversations between the pairs round the campfire end up detailing slander law, Brecht's alienation effect, and problems with parents who don't understand high-heels and jazz.

The only convincing romance, and the exception to the patterns mentioned above, is that of Brit and Wolf, which threatens to destroy the group, and that is the one which must be extinguished. Both of these characters frequently announce their own independence, saying that they do only what they want. Their individualism is unacceptable, and Stupsi takes Brit to task about her destructive vision of love and romance. Stupsi remains conspicuously unattached throughout the film, and her horror when they steal the boat is actually blamed by some of the boys on the fact that she hadn't paired off with anyone. Yet it is she who is the peacemaker, and who reunites both groups at the end. She manages to get the boys back into town after the fight without any trouble, and remains as popular and as strong as ever when Brit and Wolf are welcomed back into the fold. Her lack of romance does not bother her, and she seems actually rather proud of it. When asked at the end of the film if she has a boyfriend yet, she merely sighs, raises her eyes and leaves the question unanswered.

Rick Altman has described musicals as having dualfocus structures: they are based on the principle of pairing off two oppositions, usually along gender lines, in order to bring them together and ultimately meld them into a socially acceptable whole. The problem is that from start to 
finish the characters in Heisser Sommer are socially acceptable. The infringements they commit are minor, the authorities are understanding, and ultimately the group ends up as it started: whole, collective and entirely acceptable and unromantic. It is for this reason that the ending seems unsatisfactory. There has been no development, no movement for the characters. Stupsi remains independent, Brit "flirty", Kai dependable and Wolf is still the joker/Casanova figure. Even though the conventional love-triangle is ostensibly resolved at the end of the film, there is little narrative continuity between the ending and what precedes it. They all reconcile with their true collectivist natures and the group/collective remains far more important at the end of the film than any of the individual characters or romantic pairings. A successful love affair, whether between Wolf and Brit, or between Kai and Stupsi, would have disrupted the camaraderie and the group dynamic. The fact that this film - a youth musical must put the group above the individual, might well be read as a confirmation that romance is still distrusted by the State.

The film was very successful, but neither its production nor its success was ever repeated in the GDR. The musical, and its narrative conventions, were deemed unsuitable for real-existing socialism. Musicals are about attaining individual pleasure and social utopia - something which according to the official discourse was already abundant in the GDR. Because the state was unwilling to show antisocial behaviour by its citizens, and was unwilling to show the triumph of a romantic relationship which threatens to overwhelm the collective ideal, the unification of opposites through romance never happens in this film. Ultimately, it is the spectator who must add the ending in their own 
mind, assuming something which is never actually shown or described.

Yet the openness of the ending and the lack of an acceptable conclusion, by genre standards, also offers an explanation of why this film particularly remains such a good focus for the nostalgia that formed part of mourning the state, post 1990. As an example of "nostalgia for the cult of cinema itself" (Boym 76), the repeated, public showings of the film in the "Netflix Era" (Sterling) echo romanticised memories of what cinema used to represent: an event, a collective experience. In content too, the film offers traditional sites for nostalgia - youth, holiday trips, good clean fun, and a naiveté, which reminds everyone of the 'good old days.' It also offers to the spectator now, as it did then, a certain degree of power to create the ending of the story for themselves. As Frackman and Stewart point out in the introduction to their recent edited volume on gender and sexuality in East German cinema,

by the 1970s at the latest, East German spectators had grown accustomed to reading between the lines for social critique in films and television programming. [...] Further the disjunctions between East Germans' public and private lives add another layer of complexity to interpretations of visual presentation and representation of reality in various media. $(2018,3)$

In as much as the project of fostering love between state and citizens was an open-ended undertaking that required negotiation, so too is the project of creating new political identities and dealing with a new political past. Rather than write off such nostalgia as consumer fetishism or "powerful forgetting," (84) as Richard Esbenshade described it, it is more constructive to see it as an active process of 
remembering and negotiating with such cultural artefacts. This is a necessary process, a process required to establish new identities in a new country. Judging by the continued success of the theatrical and cinematic revivals of this musical, the negotiation with memories, and memories of the GDR, must continue even beyond thirty years past the Wende. 


\section{Works Cited}

“50 Jahre DEFA-Film Heisser Sommer." Boulevard Theater Dresden, 2018.

https:// boulevardtheater.de/produktion/50-jahreheisser-sommer-thomas-natschinski-christinedaehn.html Accessed 14. Oct 2019.

Allen, Sean, and John Sandford, editors. DEFA. East German Cinema, 1946-1992. Berghahn, 1999.

Altman, Rick. Film/Genre. British Film Institute Publishing, 1999.

Bauerkämper, Arnd. “Collectivization and Memory: Views of the past and the Transformation of Rural Society in the GDR from 1952 to the Early 1960s." German Studies Review, vol. 25, no. 2, 2002, pp. 213-225.

Berghahn, Daniela, Hollywood behind the Wall: The Cinema of East Germany. Manchester University Press, 2005.

Bernhardt, Christoph. "Planning Urbanization and Urban Growth in the Socialist Period: The Case of East German New Towns, 1945-1989." Journal of Urban History, vol. 32, no. 1, 2005, pp. 104-119.

Betts, Paul. Within Walls. Private Life in the German Democratic Republic. Oxford University Press, 2010.

Boym, Svetlana. "Post-Soviet Cinematic Nostalgia: From "Elite Cinema" to Soap Opera."

Discourse, vol. 17, no. 3, 1995, 75-84.

Caldwell, Peter. "After the 'Socialist Spring': Collectivisation and Economic Transformation in the GDR." Agricultural History, vol 85, no. 2, 2011, pp.294295.

"Die Ostsee an den Greifensteinen." Die deutsche Bühne, 2018.

https://www.die-deutsche-buehne.de/kritiken/dieostsee-den-greifensteinen. Accessed 14 Oct. 2019. 
Dyer, Richard. "Entertainment and Utopia" Movie, vol. 24, 1977, pp. 2-13.

East Side Story. Directed by Dana Ranga, Anda Films, 1997. Esbenshade, Richard. "Remembering to Forget: Memory, History, National Identity in Postwar East-Central Europe." Representations, vol. 49, 1995, pp. 72-89.

"Filme mit Freunden: Heißer Sommer," Pöge-Haus Leipzig, 2018.

https:/ / www.xn--pge-haus-n4a.de/en/pec-events/filmemit-freunden-heisser-sommer/ Accessed 14. Oct 2019.

Frackman, Kyle, and Faye Stewart, editors. Gender and Sexuality in the East German Film Industry. Intimacy and Alienation. Camden House, 2018.

Fritzsche, Sonja. "East Germany's "Werkstatt Zukunft": Futurology and the Science Fiction Films of "defafuturum." German Studies Review, vol. 29, no. 2, 2006, pp. 367-386.

Fullbrook, Mary. The People's State, East German Society from Hitler to Honecker. Yale University Press, 2005.

Grossman, Atina. Reforming Sex. The German Movement for Birth Control and Abortion Reform, Oxford University Press, 1995.

Harsch, Donna. "Society, the State and Abortion in East Germany, 1950-1972." The American Historical Review, vol. 102, no. 1, 1997, pp. 53-84.

Heckart, Beverly. "The Battle of Jena: Opposition to "Socialist" Urban Planning in the German Democratic Republic." Journal of Urban History, vol. 32, no. 4, 2006, pp. 546-581.

Heiduschke, Sebastian. East German Cinema: DEFA and Film History. Palgrave Macmillan, 2013.

Heisser Sommer. Directed by Joachim Hasler, DEFA, 1968. "Heisser Sommer." Hofkino Berlin, 2018. 
https:/ / hofkino.berlin/2018/07/20/heisser-sommer-ddr1967-freiluftkino-berlin-friedrichshain/ Accessed 14 . Oct 2019.

"Heisser Sommer," Rosa Luxemburg Stiftung Schwerin, 2018.

https://mv.rosalux.de/veranstaltung/es detail/RGUHV Lheisser-sommer/ Accessed 14. Oct 2019.

"Heisser Sommer," Museum Schloss und Fenster Senftenberg, 2018.

https:// www.lausitzerseenland.de/de/erleben/veranstal tungen/veranstaltungskalender/artikelheisser sommer.html Accessed 14. Oct 2019.

Hell, Julia. Post-Fascist Fantasies. Psychoanalysis, History and the Literature of East Germany. Duke University Press, 1997.

Herzog, Dagmar. Sex after fascism. Memory and morality in Twentieth Century Germany. Princeton UP, 2005.

Horten, Gerd. "The Impact of Hollywood Film Imports in East Germany and the Cultural Surrender of the GDR Film Control in the 1970s and 1980s." German History, vol. 34, no. 1, 2016, pp. 70-87.

Jarausch, Konrad. "Beyond Uniformity. The Challenge of Historicizing the GDR."

Dictatorship as Experience, Towards a Socio-cultural History of the GDR. ed. Konrad Jarausch, trans. Eve Duffy. Berghahn Books, 1999. 3-14.

Ladd, Brian. "Socialist Planning and the Rediscovery of the

Old City in the German Democratic Republic." Journal of Urban History, vol. 27, no. 5, 2001, pp. 584-603.

Landsman, Mark. Dictatorship and demand: the politics of consumerism in East Germany. Harvard University Press, 2005.

Marshall, Bill and Robynn Stilwell. Musicals. Hollywood and Beyond. Intellect Books, 2000. 
Merkel, Ina. Utopie und Bedürfnis. Böhlau, 1999.

Pelka, Anna. "Paper dresses in the country of peasants and workers: pop fashion in the German Democratic Republic." The Sixties. A Journal of History, Politics and Culture, vol 4, no. 3, 2011: pp. 51-68.

Poiger, Uta. Jazz, Rock and Rebels: Cold War Politics and American Culture in a Divided Germany. University of California Press, 2000.

Raundalen, Jon, "A communist takeover in the dream factory - Appropriation of Popular Genres by the East German Film Industry." Slavonica, vol. 11, no.1, 2005, pp. 69-86.

Rinke, Andrea. "Eastside stories: Singing and dancing for socialism." Film History, vol. 18, no. 1, 2006, pp 73-87.

Soldovieri, Stefan. "Socialists in Outer Space: East German Film's Venusian Adventure." Film History, vol. 10, no. 3, 1998, pp. 382-398.

Sperling, Nicole. "In the Netflix Era, Hollywood Wants to Know: What's a Movie, Anyway?" Vanity Fair, 3 May 2019,

https: / / www.vanityfair.com/hollywood/2019/05/wh at-is-a-movie-netflix-streaming-hollywood-oscars.

Accessed 12 ${ }^{\text {th }}$ December 2019.

Stitziel, Judd. Fashioning socialism: clothing, politics and consumer culture in East Germany. Berg, 2005.

Torner, Evan. "The DEFA 'Indianerfilm': Narrating the Postcolonial through Gojko Mitic." Re-imagining DEFA. East German Cinema in its National and Transnational Context. Eds. Sean Allen and Sebastian Heiduschke. Berghahn Books, 2016. pp. 227-247.

Uhlmann, Irene, editor. Kleine Enzyklopädie: Die Frau. Leipzig: VEB Verlag Enzyklopädie, 1961. 
Urang, John. Legal Tender. Love and Legitimacy in the East German Cultural Imagination. Cornell University Press, 2011.

Wierling, Dorothee. "Über die Liebe zum Staat - der Fall der DDR." Historische Anthropologie, vol. 8, no. 2, 2000, pp. 236-64.

von Ankum, Katharina. "Political Bodies: Women and Re/Production in the GDR." Women in German Yearbook, vol. 9, 1993, pp. 127-144. 